\title{
Analysis of Health Risk Due to the Presence of Radioactivity and Chemical Elements in Groundwater, Aldama Municipality, Chihuahua, Mexico*
}

\author{
Lourdes Villalba ${ }^{1 \#}$, Luis Colmenero-Sujo ${ }^{2}$, Adan Pinales-Munguia ${ }^{1}$, Guadalupe Estrada-Gutiérrez ${ }^{1}$, \\ Héctor Rubio-Arias $^{3}$, Fernando Mireles-Garcia ${ }^{4}$, Ignacio Dávila-Rangel ${ }^{4}$ \\ ${ }^{1}$ College of Engineering, Autonomous University of Chihuahua, Circuito No. 1, Campus Universitario, Chihuahua, Chih., México; \\ ${ }^{2}$ Technology of Chihuahua Institute, Chihuahua, Chih., México; ${ }^{3}$ College of Animal Husbandry and Ecology, Autonomous Univer- \\ sity of Chihuahua.Periférico Francisco R. Almada, Chihuahua, Chih., México; ${ }^{4}$ Regional Center of Nuclear Studies, Autonomous \\ University of Zacatecas, Ciprés 10, Frac. La Peñuela, Zacatecas, Zac., México. \\ Email:"mvillalb@uach.mx, apinales@uach.mx, gestrada@uach.mx, lcolmenero@uach.mx, rubioa1105@hotmail.com, \\ idavila@uaz.edu.mx
}

Received August $11^{\text {th }}, 2013$; revised September $9^{\text {th }}, 2013$; accepted October $7^{\text {th }}, 2013$

Copyright (C) 2013 Lourdes Villalba et al. This is an open access article distributed under the Creative Commons Attribution License, which permits unrestricted use, distribution, and reproduction in any medium, provided the original work is properly cited.

\begin{abstract}
There exist potential health risks due to the presence of some elements in groundwater. This study presents measurements of gross alpha and beta activity and chemical concentrations (fluorides and nitrates) in 25 water wells in Aldama municipality, Chihuahua, Mexico. Total alpha and beta emitter analyses were performed at the Academic Unit of Nuclear Studies at the Autonomous University of Zacatecas. Radioactive elements were concentrated by total evaporation. All samples were measured with a Wallac-Oy 1411 liquid scintillate with a pulse separation option (Pulse Shape Analysis) for $6 \mathrm{~h}$. Fluorine and nitrate analyses were performed at the Faculty of Engineering of the Autonomous University of Chihuahua by flow injection-hydride generation collection-atomic absorption spectrometry. Exposure levels were calculated for each well and found to exceed maximum limits allowed under Mexican law in terms of 1) gross alpha and beta activity; and 2) fluoride and nitrate concentrations. Gross alpha activity in two wells exceeded the reference value of $0.56 \mathrm{~Bq} \cdot \mathrm{L}^{-1}$. Fluorides and nitrates were found in $40 \%$ and $48 \%$ of water wells, respectively. Fluoride values were higher than $1.5 \mathrm{mg} \cdot \mathrm{L}^{-1}$, and the exposure doses for adults and children exceeded the reference value of 0.06 $\mathrm{mg} \cdot \mathrm{kg}^{-1} \cdot \mathrm{d}^{-1}$. Children are the most vulnerable, since their intake doses are near or above of $0.12 \mathrm{mg} \cdot \mathrm{kg}^{-1} \cdot \mathrm{d}^{-1}$ of the minimum level of risk for the development of skeletal fluorosis or bone fractures. On the other hand, while nitrate concentrations in water wells exceeded the drinking water limit of $10 \mathrm{mg} \cdot \mathrm{L}^{-1}$, this does not represent a serious health risk, since the calculated exposure doses for adults and children are below the chronic reference level of $1.6 \mathrm{mg} \cdot \mathrm{kg}^{-1} \cdot \mathrm{d}^{-1} \mathrm{es}-$ tablished by the USEPA.
\end{abstract}

Keywords: Dose; Fluorides; Nitrates; Public Health; Radioactivity; Well Water

\section{Introduction}

Aldama City is located in the Mexican state of Chihuahua and is part of the Municipality of Aldama. It is about $30 \mathrm{~km}$ from the most important uranium deposit in Mexico, Peña Blanca, which accounts for $60 \%$ of Mexican uranium reserves (Figure 1). A complete geological de-

\footnotetext{
${ }^{*}$ There exist potential health risks due to the presence of some elements in groundwater. This study presents measurements of gross alpha and beta activity and chemical concentrations (fluorides and nitrates) in water wells in Aldama municipality, Chihuahua, Mexico.

${ }^{\#}$ Corresponding author.
}

scription is provided by Dobson et al. [1].

There are potential health risks due to exposure to uranium (U) and radium (Ra) which are the most important alpha emitters especially in groundwater [2]. Once ingested, $U$ is preferentially deposited in kidneys and soft organs, while $\mathrm{Ra}$, with chemical properties similar to those of calcium, can be deposited in bones. Both elements are considered carcinogenic, depending on the exposure levels [3]. UNSCEAR [4] established values of doses for a given person over a period of 50 years $(70$ years for children) for radioactive material. For children 


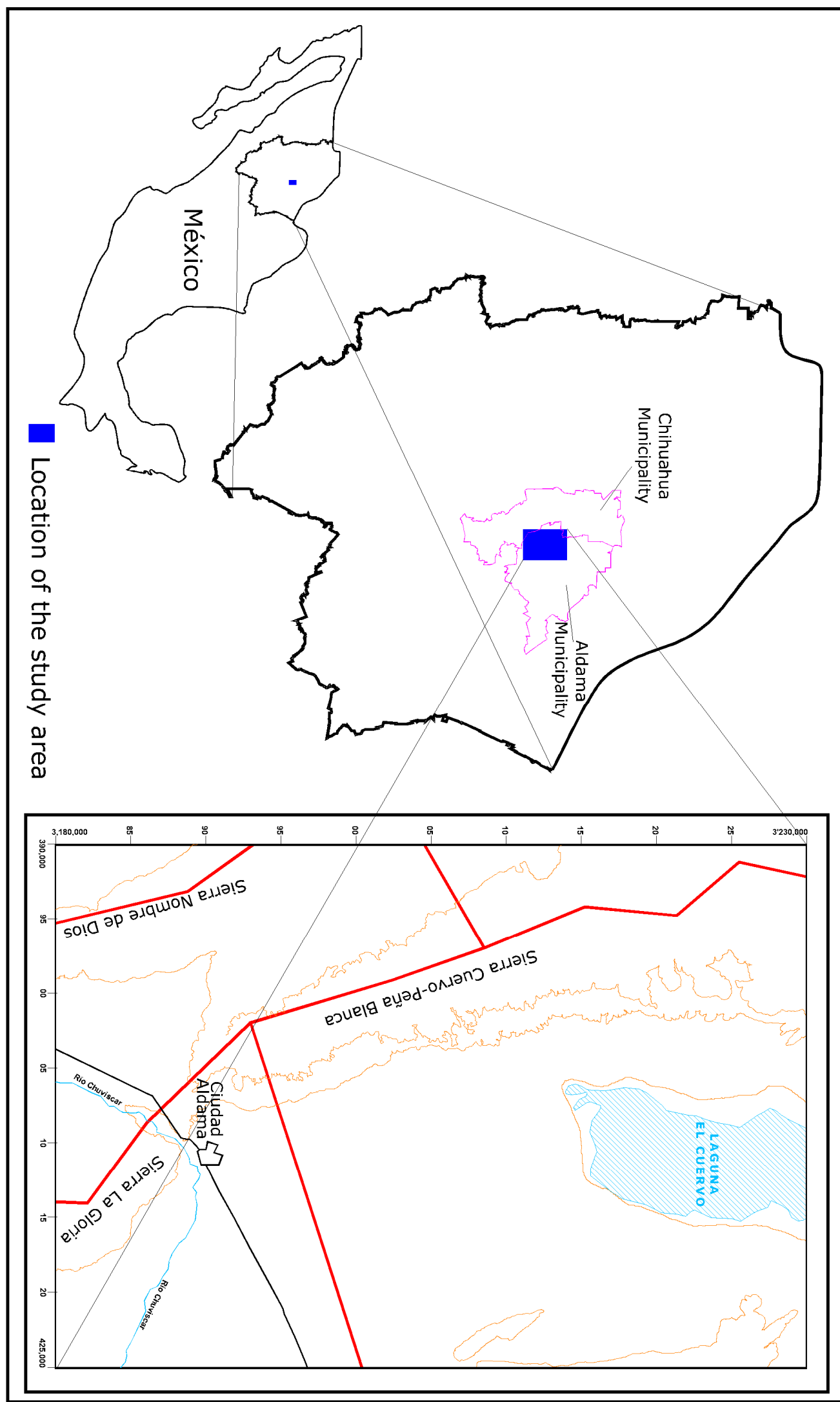

Figure 1. Location of the study area in Chihuahua, Mexico. 
(aged 7 - 12 years) and adults (17 years and older), the values are: $350 \mathrm{~L} \cdot \mathrm{y}^{-1}$, and $500 \mathrm{~L} \cdot \mathrm{y}^{-1}$, respectively.

In addition, owing to the local geology, there are other potential health hazards in Aldama municipality, such as the presence of fluoride $\left(\mathrm{F}^{-}\right)$and nitrate $\left(\mathrm{NO}_{3}^{-}\right)$in groundwater [5].

Fluorine, which is commonly referred to as its ionic form fluoride, has a chemical affinity to hydroxyapatite in bones and can thus accumulate in the skeleton, causing injuries similar to osteoporosis (skeletal fluorosis). Fluorine can also react with the enamel in teeth, leading to dental fluorosis, characterized by damage ranging from mild effects, such as spotting on the teeth, up to their total loss [6]. The calculations of fluorine exposure levels consider both children and adults with average body masses of 20 and $70 \mathrm{~kg}$, respectively. The calculations assume a daily intake of 1 liter (children) to 2 liters (adults) of water per day. The comparison reference value for fluorine is the minimum risk level calculated by the ATSDR [7], which is $0.05 \mathrm{mg} \cdot \mathrm{kg}^{-1} \cdot \mathrm{d}^{-1}$ for chronic oral exposure [8].

Interest in nitrates in water arises from the fact that they can convert blood hemoglobin to methahemoglobin, which reduces blood oxygen content, affecting cell functions and causing a disease called methahemoglobinemia [9]. Changes to the Mexican legislation established a ma-


of $10 \mathrm{mg} \cdot \mathrm{L}^{-1}$ [10], similar to the level established by the USEPA [11] and recommended by the WHO [12]. The reference level to prolonged exposure to nitrates is 6 $\mathrm{mg} \cdot \mathrm{kg}^{-1} \cdot \mathrm{d}^{-1}[13]$.

The main objective of this study was to determine gross alpha and gross beta activities as well as fluorine and nitrate concentrations in Aldama municipality well water and to calculate the exposure level of those parameters. The results presented in this paper will offer an overall assessment of the degree of radioactive and chemical elements in groundwater in northern Mexico and may be seen as an assessment of this area, which could be utilized for authorities at the federal, state and municipal levels of government in Mexico for establishing preventive actions.

\section{Materials and Methods}

Groundwater samples were collected in duplicate from 25 wells in and around the municipality of Aldama City, in the state of Chihuahua, Mexico (Figure 2). Therefore, a total of 50 water samples were collected in 1-liter polyethylene bottles. Twenty-five samples $(\mathrm{n}=25)$ were preserved following the standard methods to measure radioactivity levels [8]. The other 25 samples were preserved according to the protocol used to measure fluoride and nitrate by atomic absorption [14].
Gross alpha and gross beta emitter analyses were performed at the Academic Unit of Nuclear Studies at the Autonomous University of Zacatecas in Mexico. The protocol obtains a measurement of alpha activity from natural emitters. The radioactive elements were concentrated by total evaporation. The solid residue was dissolved with $8 \mathrm{ml}$ of di-ionized water, and mixed with 12 $\mathrm{ml}$ of OpthiPhaseHiSafe 3 Wallac scintillation liquid and stored in a polyethylene vial. Gross alpha and gross beta activities for all samples were measured with a WallacOy 1411 liquid scintillate with a pulse separation option (Pulse Shape Analysis) for $6 \mathrm{~h}$. Alpha and beta radiation were classified by a counter using a discrimination optimum pulse parameter [15]. Fluoride and nitrate analyses were performed at the Faculty of Engineering of the Autonomous University of Chihuahua by flow injection-hydride generation collection-atomic absorption spectrometry, using a Perkin Elmer 3100.

Radioactive and chemical dose calculations of groundwater samples above maximums, according to Mexican legislation, was performed taking into account the concentration of the element of interest, as well as standard values of body mass and water consumption for both adults and children [6]. Table 1 shows standard body mass and water consumption values for children and adults that were utilized in the equations. The equations used to estimate risk exposure to chemical and radioactive elements are presented below. The following equation was used to obtain the annual effective doses [4] (UNSCEAR, 2000):

$$
H E=C_{U-t} * \mathcal{Q}_{a} * D E *
$$

Where: $H_{E}$ is the effective annual dose (mSv), $C_{U-t}$ is the radioactive concentration in water $\left(\mathrm{Bq} \cdot \mathrm{L}^{-1}\right)$ and $Q_{a}$ is annual water consumption and $D E$ the dose coefficient $\left(\mathrm{mSv} \cdot \mathrm{Bq}^{-1}\right)$.

Moreover, the next equation was used to measure fluorine and nitrate exposure dose risks [16]:

$$
\text { Dose }=\frac{C * T I * F E}{P C}
$$

Where: Dose is the exposure dose by water consumption $\left(\mathrm{mg} \cdot \mathrm{kg}^{-1} \cdot \mathrm{d}^{-1}\right), C$ is the contaminant concentration $\left(\mathrm{mg} \cdot \mathrm{L}^{-1}\right), T I$ the water consumption rate $\left(\mathrm{L} \cdot \mathrm{d}^{-1}\right), E F$ the exposure factor value (a dimensional) and PC, body mass $(\mathrm{kg})$.

\section{Results and Discussion}

Results obtained in this study are presented in Table 2. In addition, Table 3 gives nitrate and fluorine exposure doses received by users of water from sampled wells in Aldama municipality.

Despite the proximity to uranium ores, only two wells 


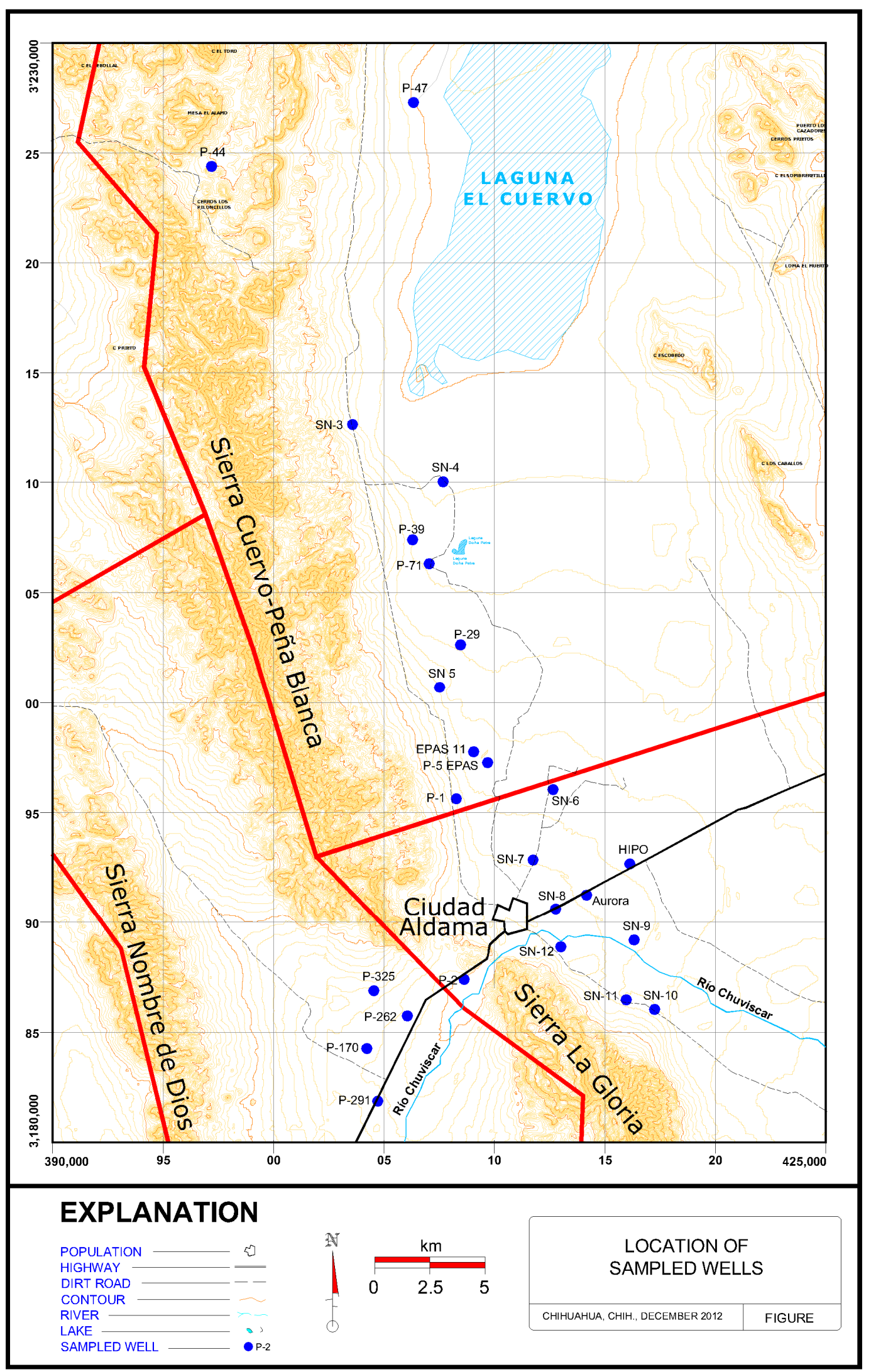

Figure 2. Location of samples wells in Aldama, Chihuahua, Mexico. 
Table 1. Standard values considered for risk analyses.

\begin{tabular}{ccc}
\hline Parameter & Adults & Children \\
\hline Body mass $(\mathrm{kg})$ & 70 & 20 \\
Water consumption $\left(1 \cdot \cdot^{-1}\right)$ & 2 & 1 \\
\hline
\end{tabular}

Table 2. Chemical and radioactive element concentrations obtained from wells in Aldama, Chihuahua, Mexico.

\begin{tabular}{|c|c|c|c|c|}
\hline \multirow[b]{2}{*}{ Wells } & \multicolumn{2}{|c|}{ Radioactive Elements } & \multicolumn{2}{|c|}{ Chemical Elements } \\
\hline & Alpha $\left(\mathrm{Bq} \cdot \mathrm{l}^{-1}\right)$ & $\operatorname{Beta}\left(\mathrm{Bq} \cdot \mathrm{l}^{-1}\right)$ & $\begin{array}{c}\mathrm{F}^{-} \\
\left(\mathrm{mg} \cdot \mathrm{l}^{-1}\right)\end{array}$ & $\begin{array}{c}\mathrm{NO}_{3}^{-} \\
\left(\mathbf{m g} \cdot \mathbf{l}^{-1}\right)\end{array}$ \\
\hline P-47 & 0.365 & 0.166 & 0.23 & 0.9 \\
\hline P-44 & 0.399 & 0.169 & 2.8 & 1.6 \\
\hline $\mathrm{SN}-3$ & ND & 0.08 & 2.2 & ND \\
\hline $\mathrm{SN}-4$ & 0.187 & 0.072 & 1.2 & 1.2 \\
\hline P-39 & 0.335 & ND & 2.7 & 0.4 \\
\hline P-71 & 0.296 & 0.077 & 1.5 & 0.8 \\
\hline P-29 & 0.174 & ND & 4.8 & 0.5 \\
\hline $\mathrm{SN}-5$ & 0.209 & 0.082 & 0.9 & 0.7 \\
\hline EPAS-11 & 0.251 & 0.147 & 1.5 & 12.1 \\
\hline P-5 EPAS & 0.337 & 0.224 & 1.1 & 21.6 \\
\hline $\mathrm{P}-1$ & 0.181 & 0.052 & ND & 4.9 \\
\hline SN-6 & 0.29 & ND & 2.2 & 3.4 \\
\hline $\mathrm{SN}-7$ & 0.505 & 0.346 & 0.9 & 20.8 \\
\hline P-291 & 0.394 & 0.187 & 2.2 & 17.8 \\
\hline P-170 & 0.744 & 0.359 & 2.9 & 21.6 \\
\hline P-262 & 0.526 & 0.329 & 2.8 & 15.1 \\
\hline P-325 & 0.217 & 0.114 & 3.3 & 2.7 \\
\hline P-2 & 1.138 & 0.226 & 2.7 & 24.2 \\
\hline $\mathrm{SN}-8$ & 0.19 & 0.313 & 1.1 & 20.2 \\
\hline AURO & 0.371 & 0.263 & ND & 7.3 \\
\hline HIPO & 0.186 & 0.264 & ND & 4.6 \\
\hline SN-12 & 0.545 & 0.382 & 0.9 & 20.7 \\
\hline SN-9 & 0.339 & 0.211 & 0.04 & 26.9 \\
\hline SN-11 & 0.407 & 0.229 & 0.90 & 16.3 \\
\hline SN-10 & 0.563 & 0.517 & 0.90 & 29.8 \\
\hline
\end{tabular}

*ND $=$ Not Detected.

(P-170 and P-2) of the 25 showed high alpha activity (Table 2) with levels of $0.744 \mathrm{~Bq} \cdot \mathrm{L}^{-1}$ and $1.138 \mathrm{~Bq} \cdot \mathrm{L}^{-1}$, respectively. These values are $33 \%$ and $103 \%$ higher than the maximum acceptable level of $0.56 \mathrm{~Bq} \cdot \mathrm{L}^{-1}[10]$. Beta emissions do not pose any risk because they are below the maximum acceptable level of $1.85 \mathrm{~Bq} \cdot \mathrm{L}^{-1}$. The value used in the effective dose calculations was the $\mathrm{U}$ concentration of $0.72 \mathrm{~Bq} \cdot \mathrm{L}^{-1}$, previously reported by Villalba et al. [2] for Aldama City. The effective adult dose is $0.023 \mathrm{mSv}$ and $0.01 \mathrm{mSv}$ for children. These values are below the annual reference dose of $0.1 \mathrm{mSv}$, for drinking water [17]. However, this effective dose only reflects alpha emission from uranium, leaving aside effective
Table 3. Fluorine and Nitrate exposure doses in groundwater in Aldama, Chihuahua, Mexico.

\begin{tabular}{|c|c|c|c|c|}
\hline & \multicolumn{2}{|c|}{$\mathrm{F}^{-}$Exposure $\left(\mathrm{mg} \cdot \mathrm{kg}^{-1} \cdot \mathrm{d}^{-1}\right)$} & \multicolumn{2}{|c|}{$\mathrm{NO}_{3}^{-}$Exposure $\left(\mathbf{m g} \cdot \mathbf{k g}^{-1} \cdot \mathbf{d}^{-1}\right)$} \\
\hline Wells & Adults & Children & Adults & Children \\
\hline P-47 & * & * & * & * \\
\hline P-44 & 0.080 & 0.140 & * & * \\
\hline $\mathrm{SN}-3$ & 0.063 & 0.110 & * & $*$ \\
\hline SN-4 & * & * & $*$ & * \\
\hline P-39 & 0.077 & 0.135 & * & * \\
\hline P-71 & * & * & * & $*$ \\
\hline P-29 & 0.137 & 0.240 & * & $*$ \\
\hline SN-5 & * & $*$ & * & * \\
\hline EPAS-11 & * & * & 0.346 & 0.605 \\
\hline P-5 EPAS & * & * & 0.617 & 1.08 \\
\hline P-1 & $*$ & $*$ & $*$ & $*$ \\
\hline SN-6 & 0.063 & 0.110 & * & * \\
\hline SN-7 & * & * & 0.594 & 1.04 \\
\hline P-291 & 0.063 & 0.110 & 0.509 & 0.890 \\
\hline P-170 & 0.083 & 0.145 & 0.617 & 1.080 \\
\hline P-262 & 0.080 & 0.140 & 0.431 & 0.755 \\
\hline P-325 & 0.094 & 0.165 & * & * \\
\hline P-2 & 0.077 & 0.135 & 0.691 & 1.210 \\
\hline $\mathrm{SN}-8$ & * & * & 0.577 & 1.010 \\
\hline AURO & * & * & * & $*$ \\
\hline HIPO & * & $*$ & $*$ & $*$ \\
\hline $\mathrm{SN}-12$ & * & * & 0.591 & 1.035 \\
\hline SN-9 & * & * & 0.769 & 1.345 \\
\hline SN-11 & * & * & 0.466 & 0.815 \\
\hline $\mathrm{SN}-10$ & * & * & 0.851 & 1.490 \\
\hline
\end{tabular}

${ }^{*}$ Does not exceed the recommended limit.

doses from all other radioactive elements (Th-230, Ra$226, \mathrm{~Pb}-210, \mathrm{Po}-210)$ in the U-238 radioactive decay series. Obviously once these are considered; the effective dose will be higher. The connection between well water radioactivity and health risk, especially for cancer has been studied overseas $[18,19]$. For instance, one study carried out in Finland concluded that radionuclide ingested through well water was not associated with a substantially increased bladder or kidney cancer rate [20].

Concentrations of fluorine range from $0.04 \mathrm{mg} \cdot \mathrm{L}^{-1}$ to $4.8 \mathrm{mg} \cdot \mathrm{L}^{-1}$ (Table 2). In 10 out of 25 wells $(40 \%)$, concentrations exceeded the acceptable level limit of 1.5 $\mathrm{mg} \cdot \mathrm{L}^{-1}$. The fluorine exposure dose due to groundwater consumption was calculated for the 10 wells with values above legal limits, obtaining values of 0.063 to 0.137 $\mathrm{mg} \cdot \mathrm{kg}^{-1} \cdot \mathrm{d}^{-1}$ for adults and 0.110 to $0.240 \mathrm{mg} \cdot \mathrm{kg}^{-1} \cdot \mathrm{d}^{-1}$ for children (Table 3). These dose values are above the reference dose value of $0.06 \mathrm{mg} \cdot \mathrm{kg}^{-1} \cdot \mathrm{d}^{-1}[10]$, which makes 
the water unhealthy for human consumption. It is possible the population drinking water from these wells may develop dental fluorosis. Dental fluorosis is an endemic disease in Mexico affecting approximately 5 million people [21]. Nevertheless, children are the most affected, because the dose values from consuming water is close to or above the $0.12 \mathrm{mg} \cdot \mathrm{kg}^{-1} \cdot \mathrm{d}^{-1}$ maximum risk level linked to the development of skeletal fluorosis or bone fractures for children [22]. This scenario gets worse when we take into account the serious nutritional deficiencies that many children in the region are subject to [21].

Nitrate concentrations range from $0.4 \mathrm{mg} \cdot \mathrm{L}^{-1}$ to 29.8 $\mathrm{mg} \cdot \mathrm{L}^{-1}$. In 12 from 25 wells $(48 \%)$ the values were above the maximum level of $10 \mathrm{mg} \cdot \mathrm{L}^{-1}$ [10]. The exposure dose was calculated for these 12 wells. Doses ranged from 0.346 to $0.851 \mathrm{mg} \cdot \mathrm{kg}^{-1} \cdot \mathrm{d}^{-1}$ in adults and from 0.605 to $1.490 \mathrm{mg} \cdot \mathrm{kg}^{-1} \cdot \mathrm{d}^{-1}$ for children (Table 3). None of the doses exceeded the chronic reference level of 1.6 $\mathrm{mg} \cdot \mathrm{kg}^{-1} \cdot \mathrm{d}^{-1}$ [11]. Craun et al. [23] performed an experiment in The United States of America with a group of 102 children of $1-8$ years of age. The children drank water with nitrate concentrations of 44 up to $500 \mathrm{mg} \cdot \mathrm{L}^{-1}$, with exposure doses ranging from 2.2 to $25 \mathrm{mg} \cdot \mathrm{kg}^{-1} \cdot \mathrm{d}^{-1}$. No cases of methahemoglobinemia have been detected in this municipality.

Another study in eleven Russian elementary schools reported that $5.3 \%$ of children age 12-14 years of age had problems related to nitrate concentrations of $105 \mathrm{mg} \cdot \mathrm{L}^{-1}$ [24]. However, we could not find any record of health issues related to water consumption of concentrations close to the $29.8 \mathrm{mg} \cdot \mathrm{L}^{-1}$ found in well SN-10. Due to all of the above reasons, nitrate concentrations in groundwater do not appear to pose any significant health risk to the population of Aldama City.

\section{Conclusion}

Alpha emitters present in 2 out of 25 wells $(8 \%)$ in $\mathrm{Al}-$ dama municipality exceeded the maximum level of 0.56 $\mathrm{Bq} \cdot \mathrm{L}^{-1}$. With regards to beta emissions, they do not pose any health risk, because all values are under the recommended limits $\left(1.85 \mathrm{~Bq} \cdot \mathrm{L}^{-1}\right)$. Fluorine levels exceeding the $1.5 \mathrm{mg} \cdot \mathrm{L}^{-1}$ maximum value were found in 10 of the 25 wells (40\%). Dose values received by adults and children exceeded the recommended ATSDR values. Nitrate concentrations above the limit of $10 \mathrm{mg} \cdot \mathrm{L}^{-1}$ established by Mexican law were found in 12 out of 25 wells (48\%). Nevertheless, calculated exposure doses were below the USEPA chronic reference level of $1.6 \mathrm{mg} \cdot \mathrm{kg}^{-1} \cdot \mathrm{d}^{-1}$. Nitrate concentrations do not appear to pose health risks to either adults or children.

\section{REFERENCES}

[1] P. F. Dobson, T. A. Ghezzehei, P. J. Cook, J. A. Rodri-
guez-Pineda, L. Villalba and R. De la Garza, "Heterogeneous Seepage at the Nopal I Natural Analogue Site, Chihuahua, Mexico," Hydrogeology Journal, Vol. 20, No. 1, 2011, pp. 155-166.

http://dx.doi.org/10.1007/s10040-011-0783-5

[2] M. L. Villalba, L. H. Colmenero-Sujo and M. E. Montero, "Analisis y Dosimetria de Radionúclidos en el Agua. Estudio Realizado en Chihuahua-Mexico," In: Leipzing, Ed., Amazon DistributionGmbH, Academica Española, 2011, p. 101.

[3] R. D. Loyd, E. Polig, F. W. Bruenger and S. C. Moller, "Uranium Skeletal Dosimetry and Distribution in Young Adult Beagles. A Guide for Calculating Uranium Skeletal Dosis in Humans," Health Physics Society, Vol. 70, No. 3, 1996, pp. 364-401.

[4] UNSCEAR, "Sources and Effects of Ionizing Radiation. Report to the General Assembly with Scientific Annexes," United Nations Scientific Committee on the Effects of Atomic Radiation, 2000.

[5] H. R. Arias, K. Wood and H. E. Alanis, "Water Pollution in the Rio Conchos of Northern Mexico," International Conference on Development and Application of Computer Techniques to Environmental Studies, 2004, pp. 167176.

[6] R. Trejo-Vazquez and A. Bonilla-Petriciolet, "Exposición a Fluoruros del Agua Potable en la Ciudad de Aguascalientes, Mexico," Revista Panamericana de Salud Publica, Vol. 10, No. 2, 2001, pp. 108-113. http://dx.doi.org/10.1590/S1020-49892001000800006

[7] ATSDR, "Toxicological Profile for Fluoride, Hydrogen Fluoride and Fluorine. Department of Health and Human Services, Public Health Service," Agency for Toxic Substances and Disease Registry, 1993.

[8] ATSDR, "Standard Practice for Conducting an Interlaboratory Study to Determine the Precision of a Test Method," Agency for Toxic Substances and Disease Registry, 1999.

[9] S. Vega, "Riesgo Sanitario Ambiental por la Presencia de Arsenico y Fluoruros en los Acuiferos de México," Technic Report: Comisión Nacional del Agua. Gerencia de Saneamiento y Calidad del Agua, 2004.

[10] NOM-127-SSA1-1994, "Norma Oficial Mexicana, Salud Ambiental. Agua Para uso y Consumo Humano. Límites Permisibles de Calidad y Tratamientos a que Debe Someterse el Agua Para su Potabilización Secretaria de Salud," 1994

[11] USEPA, "Chapter 5. Water Quality Conditions, Monitoring \& Assessment," Environmental Protection Agency of United States, 2012.

[12] WHO, "Background Document for Development of WHO Guidelines for Drinking-Water Quality. Nitrate and Nitrite in Drinking-Water," World Health Organization, Geneva, 2011.

[13] J. L. Arumi, J. Nuñez, L. Salgado and M. Claret, "Evaluacion del Riesgo de Contaminacion con Nitratos de Pozos de Suministro de Agua Potable en Chile," Revista Panamericana Salud Publica, Vol. 20, No. 6, 2006, pp. 385392. 
http://dx.doi.org/10.1590/S1020-49892006001100004

[14] NMX-AA-051-SCFI-2001, "Norma Oficial Mexicana. Analisis de Agua-Determinacion de Metales por Absorcionatomica en Aguas Naturales, Potable, Residuales y Residuales Tratadas-Método de Prueba," 2001.

[15] J. I. Davila, H. Lopez, B. L. Rodriguez and M. Solache, "Gross Alpha and Gross Beta Radioactivity in Drinking Water from Zacatecas and Guadalupe Cities, Mexico," Journal of Radioanalytical and Nuclear Chemistry, Vol. 247, No. 2, 2001, pp. 425-428.

[16] F. Diaz-Barriga, "Metodologia de Identificacion y Evaluacion de Riesgos Para la Salud en Sitios Contaminados," OPS/CEPIS/PUB/99.34. Lima Centro Panamericano de Ingenieria Sanitaria y Ciencias del Ambiente. Organizacion Mundial de la Salud, 1999.

[17] ICRP, "Recommendations of the International Commision on Radiological Protection," International Commision on Radiological Protection, Pergamon Press, Oxford, 1990, p. 60.

[18] J. M. Falcao, F. P. Carvalho, M. M. Leite, M. Alarcao, E. Cordeiro and J. Ribeiro, "MINURAR Project d Úranium Mines and Their Residues; Health Effects in a Portuguese Population. ScientificReport I," 2005.

[19] O. Neves and M. M. Abreu, "Are Uranium-Contaminated Soil and Irrigation Water a Risk for Human Vegetables Consumers? A Study Case with Solanumtuberosum L.,
Phaseolus vulgaris L., and Lactuca sativa L," Ecotoxicology, Vol. 18, No. 8, 2009, pp. 1130-1136. http://dx.doi.org/10.1007/s10646-009-0376-4

[20] P. Kurttio, L. Salonen, T. Ilus, J. Pekkanen, E. Pukkala and A. Auvinen, "Well Water Radioactivity and Risk of Cancer of the Urinary Organs," Environmental Research, Vol. 102, No. 3, 2006, pp. 333-338. http://dx.doi.org/10.1016/j.envres.2005.12.010

[21] R. Hurtado-Jimenez and J. Gardea-Torresdey, "Estimacion de la Exposicion a Fluoruros en Los Altos de Jalisco, Mexico," Salud Publica en Mexico, Vol. 47, No. 1, 2005, pp. 58-63.

http://dx.doi.org/10.1590/S0036-36342005000100009

[22] V. Hernandez, J. I. Bueno, A. M. Sanchez, J. Garcia, R. Trejo, A. Bonilla and C. Marquez, "Fluorosis y Caries Dental en Niños de 9 a 11 años del Estado de Aguascalientes, México," Revista Internacional de Contaminación Ambiental, Vol. 19, No. 4, 2003, pp. 197-204.

[23] G. F. Craun, D. G. Greathouse and D. H. Gunderson, "Methahemoglobin Levels in Young Children Consuming High Nitrate Well Water in the United States," International Journal of Epidemiology, Vol. 10, 1981, pp. 309-312

[24] N. I. Petukhov and A. V. Ivanov, "Investigation of Certain Psychophysiological Reactions in Children Suffering from Methemoglobinemia Due to Nitrate in Wáter," Gigiena i Sanitariia, Vol. 35, No. 1, 1970, pp. 29-40. 